\title{
Why some Russian industrial companies innovate regularly: Determinants of firms' decisions to innovate and associated routines*
}

Igor Gurkov ${ }^{* *}$

Through a survey of CEOs of Russian industrial companies administered in the second half of 2011 we have tried to understand the forces that lead some firms to decide to engage in more innovative activities than others and examined the types of routines associated with this decision. We found that the most important factors that predispose Russian CEOs towards regular innovations are awareness of rapid changes in technologies and products, positive assessment of the market trends and ability to orchestrate intra-industry cooperation. The most visible routine associated with more innovative behavior is the wide use of subcontractors for most of the activity related to innovations.

Mittels einer Befragung von CEOs von russischen Industrieunternehmen, durchgeführt in der zweiten Hälfte des Jahres 2011, haben wir versucht, die Kräfte zu verstehen, die einige Unternehmen dazu führen, mehr innovative Tätigkeiten zu entwickeln als andere und haben untersucht, welche Arten von Routinen mit dieser Entscheidung verbunden sind. Wir fanden heraus, dass die wichtigsten Faktoren, die russische CEOs in Bezug auf regelmäßige Innovation orchestrieren, das Bewusstsein über den raschen Wandel von Technologien und Produkten sowie die positive Einschätzung der Markttrends und die Fähigkeit der intra-industriellen Zusammenarbeit sind. Die am deutlichsten sichtbare Routine, die mit stärkerem innovativen Verhalten verbunden ist, ist der breite Einsatz von Subunternehmern bei den meisten Aktivitäten im Bereich der Innovationen.

Keywords: industrial innovations, surveys, managerial attitudes, post-recession development, Russian economy

\footnotetext{
* Manuscript received: 22.01.2012, accepted: 25.07.2012 (1 revision)

** Igor Gurkov, Distinguished University Professor, National Research University Higher School of Economics. Main research areas: industrial innovations, corporate strategies, organizational design. Corresponding address: gurkov@list.ru
} 


\section{Introduction}

For the last five years, despite the conditions of severe financial crisis and following fragile economic recovery, "modernization" has been in the list of top priorities of the Russian government. A great part of both modernization rhetoric and implemented actions has been devoted to promoting innovations at the enterprise level. Consequently, a extensive research was done on innovative activities of Russian companies. There were intensive studies on governmental innovation policies (OECD 2011a, OECD 2011b); in 2007-2012 a careful monitoring of indicators of innovative activities was performed (Gokhberg et al. 2012). Several studies were devoted to the overview innovative efforts in particular types of enterprises - in large state-owned corporations (RBC 2012), in emerging Russian multinationals (Filippov 2011), in other large Russian corporations (New Economic School, 2011), and in "ordinary" Russian manufacturing companies (Golikova et al. 2011).

Recent studies on innovation activities of Russian companies produced mixed results that enabled Gurkov (2011a) to label the situation as an "Ilya Murometz syndrome" - a combination of high capabilities and strong unwillingness to use such capabilities for real actions. Indeed, from one side,

- there has been visible state support of innovations in private companies at both the federal and regional levels (Economic Intelligence Unit 2011; Pushkarenko 2011);

- Russian manufacturing companies have demonstrated a strong capacity for imitation of products and processes (even in forms of intellectual piracy and product forgery) (Gurkov 2011b; Smirnova et al. 2012; Golichenko/Balycheva 2012); and

- the absolute majority of Russian CEOs consider innovations as a "master key" to solve most of the company's problems - from increasing profitability to "reaching a new level of quality of business" and "escaping the boredom of business routines" (Gurkov/Morgunov 2011).

From the other side,

- both the empirical and anecdotal evidence indicate low level on investments on technological innovations. For example, large companies were spending less on technological innovations than on corporate festivities (Grishankov 2009);

- innovations are not properly incorporated both in the companies' strategy processes (Gurkov 2009a) and in specific strategic programs (Litvinova/Petlevoy 2012); and

- there is insufficient pressure of shareholders on companies for innovative development (Gurkov 2011a). 
In this respect, we organized our study to discovering the Russian companies that have escaped the abovementioned "Ilya Murometz syndrome." More precisely, we aimed to understand why some Russian industrial companies are engaged in regular innovation. We set out uncover the determinants of firms' decisions to innovate regularly and possible routines that reinforce innovative behavior. The paper is organized as follows. In the next section, we explain our theoretical framework, the research instruments and describe the sample. Section 3 presents the results from the CEO survey on the factors that influence the decision of the firm to innovate. In section 4, we examine the routines that are associated with innovation activities. Section 5 contains the discussion of the major findings. Short conclusions and suggestions for further studies complete the article.

\section{Theoretical framework, research instruments and the sample}

\subsection{Definition of industrial innovation}

Innovation, which has been defined as a means '...to introduce changes and new ideas' (Procter 1995) can refer to changes and ideas which are new to the world (an invention) or new to a firm (inventions, imitations and adaptations). This paper uses the second, broader meaning.

Schumpeter (1912/1934) distinguished between five different types of innovations at the company level:

- new products,

- new methods of production,

- new sources of supply,

- exploitation of new markets and

- new ways to organize business (see Fagerberg 2003: 18).

All these actions may be pursued simultaneously by the firm. Moreover, such actions may be closely interrelated. One well-known phenomenon is the need for development of new or modified products in order to adapt to conditions of new markets. Second well-documented phenomenon is accelerated development of new methods of production through gaining an access to new sources of supply of technological solutions (strategic partners, independent technology brokers etc.) (Liuhto 2011). Finally, both product and technological innovations serve as strong impetuses for developing new ways to organize business. Thus, in our attempt to understand the reasons of regular innovations in some Russian companies we chose not to focus on narrow definition of innovation. Just the opposite, we should include all the mentioned types of innovations as exertions of firm innovation efforts. 


\subsection{Model of firm innovative behavior}

The decision by the firm to innovate should be regarded in the light of what firms aim to do. There are several competing models of firm behavior neoclassical, neo-institutional (including the stakeholder approach) and evolutionary theories. It was stressed that "neoclassical theories of firm behavior have little to say about the determinants of innovative improvements" (Webster 2004, 2-3).

Neo-institutional theories, especially the stakeholder approach, seems to be very appropriate as they attribute innovations to the pressure of stakeholders (see Jones 1998; Hall/Martin, 2005; Lewis et al. 2007; Cooperrider/Fry 2009; Talke/Salomo 2009; Sarkis et al. 2010; Pittino et al. 2011). The wider institutional environment may facilitate the translation of demands of particular stakeholders (like good practices of corporate governance facilitate the enforcement of shareholders' claims) or hamper specific demands (like poor or incomplete labor legislation defends employers from the claims of employees). Accordingly to the stakeholder approach, firms master proactive innovations in order to anticipate the future demands of stakeholders or reactive innovations to meet to the existing demands of stakeholders if such claims cannot be met by prosaic activities (see Livingston et al. 1998). However, in a recent survey Gurkov (2011a) found the negative impact of shareholders on innovativeness of Russian companies and no direct impact of other stakeholders. These findings do not mean that the neo-institutional approach is not applicable in the Russian context, but in order to reveal the factors that do affect innovativeness in Russian industries we had to look to other theoretical perspectives.

We considered evolutionary models as a possible theoretical framework for both firm's decision to innovate and accompanying routines. The evolutionary models, which owe many foundations to Nelson and Winter (1982), argue that industries, or groups of rival firms, evolve through a process involving the creation of variety (through industrial invention), inheritance (through the persistent of each firm's routines and behavioral norms) and selection (through competition and market exit). The evolution of industries requires continual cycles of invention, inheritance and selection. Although evolutionary models do not deny the importance of non-systematic individual factors for the firm's decision to be more innovative (Galende/la Fuente, 2003), the models put a great emphasis on systemic extra-firm factors associated with the prevailing technology, technological opportunities in their product area, and the external market circumstances (Dosi 1988; Arvanitis/Hollenstein 2001).

Under the evolutionary model of firm behavior, the decision over how intensively innovative activities will be pursued, will be accompanied by a series of routines and practices that (ideally) should support and nurture these activities. Evolutionary models do not specify such routines. Here the organizational design approach proposed by Miles and Snow (1978), which 
portrays practices suitable for less innovative ("Reactors" and "Defenders") and for more innovative firms ("Analyzers" and "Prospectors") may be appropriate. In the last theoretical studies within the Miles-Snow framework (Burton et al. 2011) such practices of more innovative companies such as empowerment of middle managers, maintaining (development) specific types of organizational climate are described in great details. The empirical studies, including the studies in the Russian context, also acknowledge the practices of accelerated competences' development that may take various forms (greater attention to personnel training and development, wider use of consultants and subcontractors within the cycles of innovation works) (Gurkov 2011c; Michailova/Jormanainen 2011, Weigelt/Sarkar 2012).

Thus, within the assembled theoretical framework the goals of our study was formulated as follows:

- to determine the impact of technological changes and market conditions on innovativeness;

- to discover possible non-systemic factors associated with higher innovativeness;

- to retrace in which extend the specific routines (especially empowerment of middle managers, maintaining specific types of organizational climates, greater emphasis on personnel training and the use of subcontractors for innovation works) are associated with high innovativeness in the Russian context.

\subsection{Research instruments}

The chosen survey respondents were company executives as this fit the theoretical design of the study. The technique of corporate surveys on innovativeness has been successfully used in 2000s in Russia (Gurkov 2005; Prazdanichnykh/Liuhto 2010; Golikova et al. 2011) and in other countries (see Jensen/Webster 2004; IBM 2010). For the present study, we modified the questionnaire used by Gurkov (2005).

The questionnaire consists of 16 types of actions (from "design and market launch of new products" to "acquisition of other companies"). Each item (particular action) is measured on a four-point scale - "is not considered", "under consideration", "under implementation as a pilot (unique) project", "is implemented regularly". Executives were also asked to assess difficulties in implementation of particular types of actions related to industrial innovations and to evaluate the intensity of the use of subcontractors in innovation activities. All these multi-item scales passed trough intensive reliability analysis to ensure their appropriate reliability. The validity of these scales was additionally accessed using confirmatory factor analysis. 
In addition to the questions on innovative actions, several additional questions are used to help the respondents:

- to assess the speed of changes in technologies and market conditions in their industries;

- to express their perception of the business environment (consequences of the economic crisis of 2008/2009; current trends of the firm's markets; current level of competition);

- to assess competitiveness of their firm (the level of costs, the level of prices, the level of quality versus direct competitors).

A special emphasis was put on describing the firm's organizational climate.

Burton et al. (2011) proposed to distinguish between four types of organizational climate:

- Group climate - the firm is characterized as a friendly place to work where people share a lot of themselves. It is like an extended family. The leaders of the organization are considered to be mentors and perhaps even parent figures.

- Developmental climate - the firm is characterized as a dynamic, entrepreneurial and creative place to work. People stick their necks out and take risks. The leaders are considered to be innovators and risk takers.

- Climate of internal processes - the firm is a formalized and structured place to work. Procedures govern what people do. The leaders pride themselves on being good coordinators and organizers.

- Rational goal climate - the firm is characterized as a results oriented organization. The leaders are hard drivers, producers, and competitors. They are tough and demanding.

In our survey, we asked CEOs to indicate the current and desired climates of their firms.

The questionnaire is included in Appendix 1.

\subsection{The sample}

In 2011, we administered our survey among CEOs of Russian industrial companies. The companies were carefully selected to exclude the three types of companies:

- companies of strategic importance that were entitled to state aid during the economic crisis period of the end of 2008-the beginning of 2009 (see Gurkov 2009b);

- subsidiaries of foreign firms; 
- companies located in the city of Moscow and the Moscow region, where the average income per capita is three times higher than the Russian average.

An additional condition was that the minimum size of the company was set as 150 employees (full-time).

As a result, in the June to October 2011 period we were able to receive responses from 200 CEOs of companies in 10 industries (machine-building, chemicals, textiles, timber, pharmaceuticals, electronics, construction materials etc.). The average size of companies was 1184 employee with the median size of 500. The largest company of the sample had 15,120 employees. More importantly, CEOs' assessment of the relative size of their companies roughly followed the normal distribution $-45 \%$ of the surveyed CEOs considered their companies as the "typical" company in their industries, $30 \%$ were self-evaluated as large companies and $24 \%$ of the respondents though they were at relatively smaller firms in their industries.

\section{Findings similarities and differences between "regular innovators" and other companies}

\subsection{Regular innovations in Russian industrial companies}

The first point of our study was to understand which innovative actions of Russian industrial companies have been implemented regularly in 2010-2011 (see Table 1).

Table 1: Actions regularly carried out in 2010-2011 (percentages of the surveyed companies)

\begin{tabular}{|l|c|}
\hline Action & Percentage of firms \\
\hline Purchase and installation of new equipment & 34 \\
\hline Mastering new methods of quality control & 27 \\
\hline Active recruitment of new personnel & 25 \\
\hline New methods of personnel assessment & 23 \\
\hline $\begin{array}{l}\text { Development and market launch of new products in } \\
\text { traditional markets }\end{array}$ & 23 \\
\hline Mastering new distribution channels & 22 \\
\hline $\begin{array}{l}\text { Carrying out feasibility studies of new business } \\
\text { ideas }\end{array}$ & \\
\hline
\end{tabular}




\begin{tabular}{|l|c|}
\hline $\begin{array}{l}\text { Introduction of new remuneration schemes for } \\
\text { personnel }\end{array}$ & 20 \\
\hline Mastering new sources of recruitment & 19 \\
\hline New methods of project financing & 16 \\
\hline Purchase of patents and licenses & 12 \\
\hline $\begin{array}{l}\text { Creation of new departments and other changes in } \\
\text { organizational design }\end{array}$ & 12 \\
\hline Penetration into a new sphere of activities & 9 \\
\hline Creation of subsidiaries & 4 \\
\hline Acquisition of other companies & 4 \\
\hline Selling out own patents and licenses & 4 \\
\hline
\end{tabular}

All of these actions, with the exception, perhaps, for "penetration into a new sphere of activities", "creation of subsidiaries", "acquisition of other companies" and "selling of own patents and licenses," should be the normal practice of any large and medium-size industrial company aspiring for steady development in favorable macroeconomic conditions. Thus, we excluded the four abovementioned types of actions from further analysis, and divided all the surveyed companies into three groups:

- Group 1 - companies with no regular innovations - 30\% of the sample;

- Group 2 - companies that regularly implemented in 2010-2011 from one up to three types of innovative actions $-39 \%$ of the sample;

- Group 3 - companies that regularly implemented in 2010-2011 at least four or more types of innovative actions $-31 \%$ of the sample.

The decision to form Group 3 from at least four types of actions carried out simultaneously was not taken arbitrary. We found from exploration of our data that the majority of companies with four and more types of innovations are involved in the development of new business ideas, the purchase and installation of equipment, and the active recruitment of new personnel - the core activities of industrial company's development. We also found the statistically significant differences between each created group of companies for each type of innovative actions.

We also confirmed an almost equal distribution of companies of various industries between the three groups. This enabled us to run comparison between the groups without taking into account the industrial differences. As the data to be compared was quite rich, we organized the next sections of the paper as follow: 
- Differences in perception of the environment.

- Differences and similarities in performance of the companies of different types.

- Differences in personal characteristics of CEOs of the companies of different types.

\subsection{Perception of the environment}

The most visible difference between the groups was a completely dissimilar assessment of the environment by CEOs of the companies of different types. If we have not checked beforehand for distribution of companies of various industries between the three groups, we could imagine that we surveyed companies in different industries or even in different countries. First, CEOs of companies in Group 2 and especially in Group 3 see positive changes in their markets (see Table 2).

Table 2: Assessment of the markets situation by the firm (percentages of CEO in each group)

\begin{tabular}{|c|c|c|c|c|}
\hline \multirow{2}{*}{$\begin{array}{c}\text { Groups of } \\
\text { companies }\end{array}$} & \multicolumn{4}{|c|}{ Assessment } \\
\cline { 2 - 5 } & Recession & Stagnation & $\begin{array}{c}\text { Feeble } \\
\text { growth }\end{array}$ & $\begin{array}{c}\text { Healthy } \\
\text { growth }\end{array}$ \\
\hline Group 1 & 12 & 29 & 40 & 19 \\
\hline Group 2 & 10 & 12 & 30 & 48 \\
\hline Group 3 & 6 & 8 & 30 & 55 \\
\hline
\end{tabular}

Note: approximate statistical significances of differences by Phi, Cramer's $\mathrm{V}$ and Contingency Coefficient measures are 0.003

Further, quick revival of the markets is associated with quick changes in products and production technologies (see Table 3 and Table 4). 
Table 3: Assessment of the speed of changes in production technologies (percentages of CEOs in each group)

\begin{tabular}{|c|c|c|c|c|}
\hline \multirow{2}{*}{$\begin{array}{c}\text { Groups of } \\
\text { companies }\end{array}$} & $\begin{array}{c}\text { Technologies } \\
\text { are stable }\end{array}$ & $\begin{array}{c}\text { Technologies } \\
\text { are changing } \\
\text { slowly }\end{array}$ & $\begin{array}{c}\text { Technologies } \\
\text { are changing } \\
\text { quickly }\end{array}$ & $\begin{array}{c}\text { Technologies } \\
\text { are changing } \\
\text { extremely } \\
\text { quickly }\end{array}$ \\
\hline Group 1 & 32 & 61 & 5 & 2 \\
\hline Group 2 & 19 & 65 & 14 & 2 \\
\hline Group 3 & 6 & 47 & 39 & 8 \\
\hline
\end{tabular}

Note: Eta $=0.405$; approximate statistical significance of differences by Phi, Cramer's V and Contingency Coefficient are 0.000

Table 4: Assessment of the speed of changes in products (goods and services) (percentages of CEOs in each group)

\begin{tabular}{|c|c|c|c|}
\hline & \multicolumn{3}{|c|}{ Assessment } \\
\cline { 2 - 4 } & $\begin{array}{c}\text { There are no } \\
\text { new products }\end{array}$ & $\begin{array}{c}\text { New products } \\
\text { appear rarely }\end{array}$ & $\begin{array}{c}\text { New products } \\
\text { appear } \\
\text { regularly }\end{array}$ \\
\hline Group 1 & 40 & 44 & 16 \\
\hline Group 2 & 28 & 54 & 18 \\
\hline Group 3 & 16 & 38 & 46 \\
\hline
\end{tabular}

Note: Eta $=0.298$; approximate statistical significance of differences by Phi, Cramer's V and Contingency Coefficient are 0.000

Besides the assessment of the speed in changes in products and production technologies, we studied possible differences in parameters of "microenvironment" such as the level of competition and coordination of actions between the firms in the same industry, the level of involvement of controlling shareholders in strategic and operational issues, firm's abilities to cope with the changes in governmental regulations of business. We found the following significant results:

- companies of different innovative groups do not differ by the assessment of the level of competition;

- we were unable to find difference in the degree of involvement of shareholders into strategic and operational issues;

- companies of different innovative groups demonstrated similar abilities to cope with the changes in governmental regulations of business. 
At the same time, companies of different innovative types presented rather dissimilar pictures of their industries regarding the abilities of the firms to coordinate their actions. This was a question of indirect self-assessment - in reality by assessing the practices of colleagues the surveyed CEOs revealed their own predisposition to coordinate firm's actions. It seems that this trick worked and respondents "swallowed the bait" (see Table 5).

Table 5: Assessment of the abilities to coordinate firms' actions in the industry (percentages of CEOs in each group)

\begin{tabular}{|c|c|c|c|c|}
\hline \multirow{2}{*}{$\begin{array}{c}\text { Groups of } \\
\text { companies }\end{array}$} & $\begin{array}{c}\text { There is no } \\
\text { coordination }\end{array}$ & $\begin{array}{c}\text { Firms } \\
\text { sometimes } \\
\text { coordinate } \\
\text { their actions }\end{array}$ & $\begin{array}{c}\text { Firms } \\
\text { regularly } \\
\text { coordinate } \\
\text { their action on } \\
\text { a broad range } \\
\text { of issues }\end{array}$ & $\begin{array}{c}\text { Firms } \\
\text { constantly } \\
\text { coordinate } \\
\text { all their key } \\
\text { actions }\end{array}$ \\
\hline Group 1 & 32 & 40 & 12 & 16 \\
\hline Group 2 & 43 & 29 & 21 & 7 \\
\hline Group 3 & 27 & 19 & 31 & 23 \\
\hline
\end{tabular}

Note: Eta $=0.225$; approximate statistical significance of differences by Phi, Cramer's V and Contingency Coefficient are 0.007

We found a non-linear relationship between the intensity of regular innovations and the coordination practices within industries. A majority (54\%) of CEOs of Innovative Group 3 reported regular and intensive coordination of firms' actions in their industries. From the other side, passive firms (Group 1) reported their inclination towards frequent but occasional cooperation (40\% of firms in Group 1) and further $38 \%$ of firms of Group 1 do not miss the opportunities of regular coordination. Companies of Group 2 prefer to stay along as they reported the minimal level of coordination in their industries.

So far, we demonstrated that CEOs of "regular innovators" justify innovation activities through higher concern about the future of the firm through the acknowledgement of rapid changes in product technologies and products. At the same time, we confirmed the absence of the usually mentioned "external drivers" of innovations. Neither competition, nor the pressure of stakeholders led firms to engage in regular innovations. In addition, the government economic policy in Russia may be called as "neutral" - it neither stimulates nor hampers regularity of business innovations in "ordinary Russian industrial companies".

We also demonstrated that intra-industry coordination is a double edged sword as it is used by both inert and active firms - passive firms prefer occasional 
coordination on clearly defined narrow issues, active firms are capable to enter into regular networks of coordination.

\subsection{Differences and similarities in company performance}

Performance of companies of different types was evaluated using the following parameters:

- Assessment by CEOs of the current economic situation and the recent trends in the economic situation of their companies.

- Assessment by CEOs of the competitiveness of their companies regarding the direct competitors (prices, quality, costs).

Assessment of the current situation and the recent trends of economic situation strongly coincides with the number of regularly implemented innovations (approximate significance of Phi and Cramer's V is 0.008 for the current situation and 0.009 for the assessment of performance changes in the past few years) $-44 \%$ of CEOs of Group 3 assess the situation of their companies as "good" while for Group 2 this figure is $30 \%$ and for Group $1-$ merely $13 \%$. The improvement of economic situation reported $60 \%$ of CEOs of Group 3, around $50 \%$ of CEOs in Group 2, and 29\% of CEOs in Group 1.

Our initial assumption was to attribute the positive trend in firms' performance to the presence or the scope of innovations at the firm. This idea was strengthened as we compared competitiveness indicators between the groups.

Although there are no differences in perceived level of costs between the groups, we found statistically significant differences for other competitiveness indicators. First, there were strong differences in pricing policies between Group 1 and Group 3 - while companies in Group 1 prefer to keep average prices (78\% of companies in Group 1 indicated their prices as average), companies of Group 3 demonstrated high variety in their pricing policies $-25 \%$ of companies of Group 3 maintain higher prices, and 23\% of companies in Group 3 try to maintain lower prices. We also may see in Group 3 a non-transitive relationship between the perceived quality and the perceived prices. If higher prices in $85 \%$ of such cases are proved by CEOs' beliefs in superiority of quality of their products, lower prices do not indicate the perceived compromises on quality. For example 30\% of companies in Group 3 that reported lower prices indicated that their quality is average and $70 \%$ of such companies reported that the quality of their products is above average.

As the result of the mixed pricing techniques used by the companies in Group 3, we also may indicate that intensive regular innovations give to Russian industrial companies better chances to achieve superior profitability of sales (measured as perceived prices minus perceived costs) but does not guarantee it (see Table 6). 
Table 6: Assessment of the relative profitability of sales (perceived prices minus perceived costs) (percentages of CEOs in each group)

\begin{tabular}{|c|c|c|c|}
\hline \multirow{2}{*}{} & \multicolumn{3}{|c|}{ Assessment } \\
\cline { 2 - 4 } & $\begin{array}{c}\text { Costs are higher } \\
\text { than prices }\end{array}$ & $\begin{array}{c}\text { Costs are equal } \\
\text { to the prices }\end{array}$ & $\begin{array}{c}\text { Costs are lower } \\
\text { than prices }\end{array}$ \\
\hline Group 1 & 36 & 57 & 7 \\
\hline Group 2 & 24 & 67 & 9 \\
\hline Group 3 & 30 & 47 & 23 \\
\hline
\end{tabular}

Indeed, numerous regular innovations are engaged in risky strategies that in more than half of the firms that follow this strategy have either abnormally high or abnormally low profits. In general, we may conclude that intensity of innovations is related to performance, but we cannot confirm the causality of this relationship. A reported positive assessment of the current performance may be affected by the desire of the surveyed CEOs to prove the rationality of innovative behavior while the analysis of the more "neutral" questions on competitiveness suggests that regular innovations in the present conditions is a risky strategic posture. There are the greater chances for regular innovators to reach superior profitability of sales, but the chances to experience systemic losses are almost the same as for inert companies and are significantly higher that for the companies with a narrow scope of regular innovations.

\subsection{Personality of "regular innovators"}

Based on the results reported in the previous sections, we may describe CEOs of companies that regularly undertake numerous innovative actions as "collaborative optimistic alarmists with a high risk propensity". Indeed, CEOs of companies in Group 3:

- assess positively the current trends in their markets;

- are inclined towards coordination of their activities with competitors and the regular use of subcontractors for implementation of works related to innovations.

At the same time:

- they are trying to keep up with the rapid changes (that are often invisible to their competitors) in technologies and products in their industries;

- their actions resulted in either superior or inferior profitability of their companies.

In this respect, we decided examine in greater detail CEOs in Group 3 and to see if they differ from their colleagues in Group 1 and Group 2. 
There were no gender differences between CEOs from different groups of companies - in all the groups $69-70 \%$ of the surveyed CEOs are males. There were also no differences in the level of CEOs' participation in ownership of their companies $85-87 \%$ of the surveyed CEOs in each group either do not own the shares in their companies or have small (non-blocking) holdings. The allocation of working time between various types of activities (i.e. work with documents, meetings, negotiations, visiting the shop floor) also does not differ for CEOs from different groups.

However, we were able to find one important area of difference in the age of the CEO. The significance of mean difference for the age of the CEOs of the different groups is 0.075 . The median age of CEOs in Group 3 is 50 years, in Group $2-48$ years, in Group $1-44$ years. More importantly, the share of CEOs who are older than 41 years is $71 \%$ in Group 3, 69\% in Group 2 and only 59\% in Group 1.

We put especial emphasis on the cut-off point of the age of 41. Taking into account that $100 \%$ of the surveyed CEOs have graduate diplomas $(50 \%$ in economics and business studies, and $42 \%$ in engineering), and remembering that the usual length of university studies in Russia is 5 years, the age of a CEO of 41 years means that such persons have no Soviet working experience as they started their working life on or after1991 the same time as the centrally planned system collapsed.

\subsection{Integrated analysis of similarities and differences of regular and occasional innovators}

To determine the relative importance of the identified factors that delineate routine innovators with occasional innovators we performed an integrated analysis. We used discriminant analysis trying to distinguish companies in Group 3 (regular innovators) from companies in Group 1 (occasional innovators). To understand the relative importance of classification parameters we used a special method that is not included into standard SPSS package, but that is easy to perform. We mean here the analysis of the products of standardized canonical discriminant function coefficients and structure matrix coefficient. The total sum of such products is equal to 1.00; the particular product serves as an analogue of the explained share of variance in the multivariate analysis of variance.

The possible predictors of innovative behavior, included into the discriminant function, were:

- assessment of the current situation of the markets,

- perception of the speed of changes in industry's products,

- perception of the speed of changes in production technologies, 
- assessment of the ability of firms to coordinate their activities;

- the age of the surveyed CEO.

We were able to classify properly $76 \%$ of companies in Group 1 and $74 \%$ of companies of Group 3. The almost equal shares of properly classified cases in the both groups indicate that the set of selected discriminating variables affects equally the both groups. This increases the probability that we are able to focus on the phenomenon under investigation concerning the willingness and capacities for regular innovations in many areas.

The results of computations of the products of standardized canonical discriminant function coefficients and structure matrix coefficients are presented in Table 7.

Table 7: Products of standardized canonical discriminant function's coefficients and structure matrix coefficients

\begin{tabular}{|l|c|}
\hline Variable & Value of the product \\
\hline $\begin{array}{l}\text { Perception of the speed of changes in production } \\
\text { technologies }\end{array}$ & 0.348 \\
\hline $\begin{array}{l}\text { Perception of the speed of changes in industry's } \\
\text { products }\end{array}$ & 0.253 \\
\hline Current situation of the markets & 0.235 \\
\hline Age of the surveyed CEO & 0.090 \\
\hline The level of coordination of competitors' actions & 0.075 \\
\hline
\end{tabular}

Note: The total sum of products is equal to 1.00

So far, the CEOs perception of the speed of changes in industry's products, their perception of the speed of changes in production technologies and assessment of the market conditions totaled up to $83.5 \%$ of the discriminating power applied to separate between passive firms and active innovators. We may clearly see that the perception of the changes in technologies is the most important discriminating factor. The second and the third places are almost equal in importance and are occupied by the perception of the changes in products and the assessment of the current situation of the markets. The found dissimilarities between Group 1 and Group 3 in the age of the firm's CEOs and ability to coordinate activities of firm play subordinated roles in distilling from the general sample the inert and active companies. These results strongly support the evolutionary models of innovations put a great emphasis on systemic extrafirm factors associated with the prevailing technology, technological opportunities in their product area, and given external market circumstances. 


\section{Accompanying routines}

Based on both theoretical and empirical literature, we stipulated four types of routines that should be observed in innovatively active firms the empowerment of middle managers, maintaining specific types of organizational climates, greater emphasis on personnel training and the use of subcontractors for innovation works. The survey data did not in general support these theoretical predictions.

First, we were unable to find empowerment of middle managers in innovatively active firms, especially in the key area of managers' discretion sucha the right of middle managers to control budgetary issues.

Second, we were unable to find statistically significant differences in opinions of CEOs of different groups neither about the observed organizational climates nor about the desired climates. Following (Burton et al. 2011), active innovators should strive to maintain in their companies "developmental climate" or at least "climate of rational goals". However, in reality only a quarter of CEOs in Group 3 wish to establish in their companies the climate of rational goals and only $17 \%$ wish to establish the developmental climate. Instead, a half of CEOs in Group 3 observes and wishes to maintain the climate of internal processes, i.e. to manage formalized and structured place to work.

We also were unable to find statistically significant differences in the amounts spent on personnel training and development in different groups of companies.

The only routine that strongly differentiates active innovators from other firms is the use of subcontractors. Firms in Group 3 differ from firms in Group 1 and Group 2 in every aspect of the use of subcontractors. We may that in "hard matters" (related to purchase and installation of new equipment) two thirds of companies in Group 3 rely on subcontractors. In marketing and HRM issues the role of subcontractors is lower, but also important (see Table 8).

Table 8: The use of subcontractors in for innovative activities in group 3 (Percentages of companies that use them actively)

\begin{tabular}{|l|c|}
\hline Type of works & Percentage \\
\hline Technology and production facilities development \\
\hline Installation of new equipment & 70 \\
\hline Purchase of necessary equipment & 65 \\
\hline Access to production technologies & 47 \\
\hline Mastering new methods of quality control & 42 \\
\hline Marketing and GR issues & 49 \\
\hline Understanding customers' needs
\end{tabular}




\begin{tabular}{|l|l|}
\hline Obtaining necessary government licenses and certificates & 44 \\
\hline Design of new products & 43 \\
\hline Mastering new distribution channels & 39 \\
\hline Search for new business ideas & 37 \\
\hline Promotion and advertising of new products & 35 \\
\hline Human resource management issues & 57 \\
\hline Staffing by qualified workforce & 40 \\
\hline Mastering new methods of personnel assessment & 38 \\
\hline Mastering new remuneration schemes & 34 \\
\hline Mastering new methods of personnel training & \\
\hline
\end{tabular}

However, we cannot claim the active use of subcontractors in Group 3 as the fact of accomplished accumulation of competences. Quite the opposite, in most of the cases there are significant positive correlations between the use of subcontractors and the experienced difficulties in performing specific innovation activities. The detailed analysis of survey results reveals that subcontractors are used as substitutes for organizational weaknesses - they do not make the business activities less difficult, but outside contracting are related to the inability to achieve the desired outcomes within the existing organizational settings of the firm. For example, the active use of subcontractors for the search of innovative ideas is related with inability to create innovative ideas from the existing personnel or the designated departments. One partial exception here is the use of subcontractors for the purchase and installation of new equipment again subcontractors do not make the corresponding works much easier, but they are called for more often in two cases -- when the company experiences minimal difficulties in getting finance for new projects or when the company may afford the "luxury" to include additional expenses related to subcontractors into the prices for its own products.

\section{Discussion}

Our insights into why and how "genuine Russian industrial companies" innovate touch several important issues of innovation studies. First, although our study confirms the importance of the speed of changes in market and technologies for the decisions to innovates we found that the factors usually mentioned as "triggers" or moderators of innovations are lacking - the role of competition for direct promoting innovative behavior is weak and most existing firm routines are not supportive to innovative behavior.

Our results demonstrate that the impact of competition, usually stressed in many studies as the important trigger of innovations (see Kleinknecht 1996; Athreye 
2001) is not always a necessary condition. Indeed, if the level of competition is not sufficient to ensure the regular exit of ineffective firms (and in most Russian industries this is just the case), competitors are transformed into "business partners" - they may serve (voluntarily or involuntarily) as the suppliers of innovative ideas for active innovators. If the innovativeness is low, companies just demarcate their market domains. The both types of behavior were revealed in our study. Innovatively active companies (group 3) enter into regular coordination networks with (presumably) similar "partners", but inert companies also frequently enter coordination agreements on narrow issues.

The weakness of supportive routines, especially low level of rights of middle managers and the reluctance of CEOs to create organizational climates suitable for active innovators demonstrates low "rootedness" of intensive innovations in Russian industries. Russian executives embark on intensive innovations in order to capture the positive market opportunities and to be in tune with the changes in markets and technologies, but they are trying to return their companies back into "normal functioning" as the situation deteriorates. The reluctance of Russian top executives to create organizational structures and climates more suitable for intensive innovations comes at high price - innovatively active companies have to use the costly services of subcontractors in order to substitute the inability (or unwillingness) of their own managers and engineers to put forwards and to realize innovative ideas.

Our study also revealed the importance of subjective perception of the environmental conditions - the point usually missed in evolutionary models. The discovered negligible role of competition, the lack of government's pressure and the unimportance of corporate governance issues as determinants of innovations activities clearly indicate a unique situation Russia companies have found themselves in the second half of 2009 and the first half of 2011 -- the complete absence of external pressure on firms regarding the scale and scope of innovation actions. The importance of internal factors determining a firm's innovative behavior was suggested in previous studies (see, for example Galende/de la Fuente 2003), but for the first time we met the situation when innovation policy of the firms was left at complete discretion of companies' top executives. In this respect, subjective factors (perceptions, attitudes and capacities of CEOs) became the major predictors for firms' innovative posture as was indicated in our analysis. Our analysis revealed that the important driver of regular innovations is positive assessment of the current market trends. The positive assessment of the current market trends may be both situational and systemic. As we have not found industry differences between inert and innovatively active companies, we suppose that the systemic factor (a generally optimistic personality of a CEO, his/her abilities to recognize positive market signals or treat market signals as opportunities) prevails. A recent study by GE Capital addressed the issue of optimism in innovations (see GE 2011), there is 
further empirical and even theoretical evidence that "optimism is an essential ingredient for innovation" (see Rigotti et al. 2011). However, most of the study on optimism is done within the context of entrepreneurial behaviour and startups, while the surveyed CEOs of Russian innovative companies do not wish to consider themselves as entrepreneurs and rather that they manage established firms. So, we deal here with another type of optimism - optimism of running business against the negative elements in the environment and the courage to turn such factors into positive ones.

Here we address the factors that also turned to be important predictor of regular innovations in Russian industrial firms - the perception of rapid changes in technologies and products. The survey data suggests there are higher chances for such changes to be endogenous, as the proportion of active innovators in our sample is not high, while regular innovations in products were observed in merely $23 \%$ of the surveyed firms. As we surveyed "genuine Russian industrial firms", we may speculate the actions of Russian subsidiaries of foreign MNCs or simply the flows of imported goods in respective markets may create such perceptions. The World Bank is assertive that the recent accession of Russia into World Trade Organization (WTO) is a unique and important opportunity for Russia's economic development (Word Bank 2012). In this respect, the may complement the World Bank's assertiveness by the beliefs that accelerated speed of changes in products and technologies provoked by WTO accession may lead to an increase of the share of domestic companies that are involved in regular innovations. In this respect, one important suggestion for Russian policy makers is to launch an intensive "propaganda" campaign focusing on opportunities to innovate through the WTO accession. The related suggestion to local executives is to believe in revealed opportunities and to exploit them by regular innovations.

\section{Conclusions, limitations and invitation for further studies}

We have seen that a survey of corporate executives on drivers of innovations brought interesting and sometimes unexpected results on the relative importance of particular factors of business environment on the decision to innovate. Positive assessment of the current market situation coupled with positive feelings towards quick changes in products and technologies justify most of innovative decisions of Russian CEOs. At the same time, the organizational impact of regular innovative activities is purposely kept limited; there are no deep changes in organizational structures and climates usually associated with intensive innovative behavior of companies.

Our study does have limitations due the research design. First, we surveyed companies that are neither "national champions" (entitled to governmental aid or, at least, governmental attention to their needs) nor subsidiaries of major multinational corporations (that have a direct access to pools of resources and 
competences of parent companies or subsidiaries in other countries). Second, we studied a limited sample of companies on a very specific stage of the business cycle immediately after a deep economic recession and during the period of fragile economic recovery. Third, although we identified many factors that surprisingly do not affect innovative behavior of Russian industrial companies, in determining the factors that do affect innovative behavior of Russian industrial companies we were able to identify properly with the help of that factors only $75 \%$ of either inert or innovative active companies. This means that we might miss additional important factors that were either missed in data analysis or, more probably, were missed in research instruments.

Despite the abovementioned limitations of our study, we believe that the observed patterns of behavior (capturing the opportunities to innovate while preserving the routines and behavioral norms of inert companies) that may be a customary practice of manufacturing companies in other countries during the times of fragile economic recovery. Although we have had no chances to make international comparison with the similar data, we wish to present such an opportunity to other researchers. For this Appendix 1 contains major parts of the questionnaire used in the survey of Russian executives in 2011. We invite researchers from other countries to use these instruments. As the world economy has not exited yet the period of fragile recovery, the international comparison of drivers for innovations, institutional environments and accompanying routines will further expand our understanding of innovative behavior of industrial companies and may contribute to theory development and non-trivial suggestions for both company managers and policy-makers.

\section{Acknowledgements}

This study was carried out within "The National Research University Higher School of Economics' Academic Fund Program in 2012-2013, research grant No. 11-01-0022". The survey was administered with support of the research grant of the Faculty of Management, National Research University Higher School of Economics. The valuable comments of Prof. Alexander Settles and two anonymous referees on the earlier drafts are acknowledged. 


\section{References}

Arvanitis, S./Hollenstein, H. (2001): The determinants of the adoption of advanced manufacturing technology, in: Economics of Innovation and New Technology, 10, 377-414.

Athreye, S. (2001): Competition, rivalry and innovative behaviour, in: Economics of Innovation and New Technology, 10, 1-23.

Burton, R./Obel, B./DeSanctis, G. (2011): Organizational design: A step-by-step approach. $2^{\text {nd }}$ ed. Cambridge: Cambridge University Press.

Cooperrider, D./Fry, R. (2009): A Peter Drucker moment: Harnessing the innovationgenerating potential of a shareholder and stakeholder theory of the firm, in: Journal of Corporate Citizenship, 36, 3-6.

Dosi, G. (1988): Sources, procedures and microeconomic effects of innovation, in: Journal of Economic Literature, 26.

Economic Intelligence Unit (2012): Russia: Chasing innovation, in: Business Eastern Europe, $40,13,1$.

Fagerberg, J. (2003): Innovation: A guide to the literature. Mimeo. Oslo: University of Oslo.

Filippov, S. (2011): Innovation and R\&D in emerging Russian multinationals, in: Economics, Management, and Financial Markets, 6, 1, 182-206.

Galende, J./de la Fuente, J. M. (2003): Internal factors determining a firm's innovative behaviour, in: Research Policy, 32, 715-736.

GE Capital (2011): The innovation optimism paradox. World Economic Forum http://www.gecapital.com/en/insights-trends/insights/innovation-optimismparadox.html

Gokhberg, L./Kuzminov, Y./Laikam, K./Naumov, A./Ponomarev, A./Ryzhikova, Z. (eds.) (2012): Indicators of innovation activities 2012. Moscow: National Research University "Higher School of Economics".

Golichenko, O./Balycheva, Y. (2012): Intellectual property and market behaviour in Russia, in: Proceedings of the European Conference on Intellectual Capital, 220-229.

Golikova, V./Gonchar, K.R./Yasin, E.G./Kuznetsov, B.V./Dolgopyatova, T.G./Yakovlev, A.A. (2011): Russian Manufacturing Revisited: Industrial Enterprises at the Start of the Crisis, in: Post-Soviet Affairs, 4, 366 - 386.

Grishankov, D. (2009): Largest corporations are spending on innovations less then half of percent (of sales). The spending on corporate celebrations is comparable, in: FinamFM. 15 June 2009, 09:96, http://www.unova.ru/article/1043 (accessed December 25, 2011) [in Russian].

Gurkov, I. (2011a): Explaining the "Ilya Muromets Syndrome" of business innovations in Russian industries, in: Journal of East-West Business, 17, 2-3, 120-131.

Gurkov, I. (2011b): Michailova and Jormanainen, "Knowledge transfer between Russian and Western firms: whose absorptive capacity is in question?": A reply, in: Critical Perspectives on International Business, 7, 4, 343-349. 
Gurkov, I. (2011c): Innovative actions and innovation (in)capabilities of Russian industrial companies - A further extension of observations, in: Post-Communist Economies, 23, 4, 507-516.

Gurkov, I. (2005): Innovations in Russian industries: conditions for implementation and impact on competitiveness, in: Journal for East European Management Studies, 10, 3, 218-246.

Gurkov, I. (2009a): Strategy process and formulation and realization of corporate goals: A synthesis of surveys in Russian firms, in: Journal for East European Management Studies, 14, 1, 48-64.

Gurkov, I. (2009b): The strategy process in Russian 'non-strategic' companies: Coping with economic recession, in: Post-Communist Economies, 21, 4, 439-451.

Gurkov, I./Morgunov, E. (2011): Motives to innovate of Russian CEOs, in: Industrial Economics and Organization, 2, 84-96 [in Russian.]

Hall, J. K./Martin, M.J. (2005): Disruptive technologies, stakeholders and the innovation value-added chain: a framework for evaluating radical technology development, in: R\&D Management, 35, 3, 273-284.

IBM (2010): Innovation index of Australian industry. Melbourne: Melbourne Institute for Applied Economic and Social Research.

Jensen, P.H./Webster, E. (2004): Examining biases in measures of firm innovation, Intellectual Property Research Institute of Australia (IPRIA) Working Paper no. 05/04.

Jones, O. (1998): From maturity to entrepreneurship: A stakeholder model of innovation, in: Creativity \& Innovation Management, 7, 2, 107-114.

Kleinknecht, A. (ed.) (1996): Determinants of innovation. The message from new indicators. Hampshire and London: Macmillan, 1996.

Lewis, M./Young, B./Mathiassen, L./Rai, A./Welke, R. (2007): Business process innovation based on stakeholder perceptions, in: Information Knowledge Systems Management, $6,1 / 2,7-27$.

Litvinova, A./Petlevoy, V. (2012) Innovation plans of companies are considered as nonambitious. RBC Daily. 27 June 2012 [in Russian].

Livingston, L.P./Palish, L.T./Carini, G.A. (1998): Viewing strategic innovation through the logic of contradiction, in: Competitiveness Review, 8, 1, 46-54.

Liuhto, K. (2011): The EU-Russia innovation cooperation: some experiences emerging from Finnish-Russian innovation collaboration, in: Journal of East-West Business, 17, 2/3, 156-169.

Michailova, S,/Jormanainen, I. (2011): Knowledge transfer between Russian and Western firms, in: Critical Perspectives on International Business ,7, 3, 250-270.

Miles, R. E./Snow, C. C. (1978): Organizational strategy, structure and process. New York: McGraw-Hill.

Nelson, R. R./Winter, S. G. (1982): An evolutionary theory of economic change. Cambridge, MA and London: Belnap Press of Harvard University Press.

New Economic School et al. (2010): Innovation activities of large Russian business, in: Russian Journal of Management, 8, 4, 81-112. 
OECD (2011a): OECD Reviews of innovation policy: Russian Federation 2011, Paris: OECD Publishing.

OECD (2011b): OECD Economic surveys: Russian Federation. Paris: OECD Publishing.

Pittino, D./Visintin, F./Compagno, C. (2011): Front end innovation and stakeholder involvement in machine tools sector, in: International Journal of Entrepreneurship \& Innovation Management, 14, 1, 96-112.

Prazdanichnykh, A./Liuhto, K. (2010): The Russian enterprise directors' perceptions on the innovation activity of their company: A briefing of the empirical results, in: Journal for East European Management Studies, 15, 4, 361-368.

Procter, P. (Ed.) (1995): Cambridge international dictionary of English. Cambridge: Cambridge University Press, 1995.

Pushkarenko, A. B. (2011): Support for innovation-active firms in the regions, in: Problems of Economic Transition, 53, 11, 15-22.

Rigotti, L./Ryan, M./Vaithianathan, R. (2011): Optimism and firm formation, in: Economic Theory, 46, 1, 1-38.

Sarkis, J./Cordeiro, J.J./Vazquez Brust, D. (Eds.) (2010): Facilitating sustainable innovation through collaboration: A multi-stakeholder perspective. Dordrecht and New York: Springer.

Schumpeter, J. (1912/1934): The theory of economic development: An inquiry into profits, capital, credit, interest, and the business cycle. Cambridge, MA: Harvard University Press.

Smirnova, M.M./Podmetina, D./Votonen, J./Torkkeli, M. (2012): Collaborative approaches to new product development: the case of Russia, in: International Journal of Entrepreneurship \& Innovation Management, 15, 1/2, 91-107.

Talke, K./Salomo, S. (2009): Launching technological innovations: the relevance of a stakeholder perspective, in: International Journal of Technology Marketing, 4, 2-3, 248-274.

Webster, E. (2004): Firms' decisions to innovate and innovation routines. Melbourne Institute Working Paper No. 5/03.

Weigelt, C./Sarkar, M.B. (2012): Performance implications of outsourcing for technological innovations: Managing the efficiency and adaptability trade-off, in: Strategic Management Journal, 33, 2 , 189-214.

World Bank (2012): Moderating risks, bolstering growth. Russian economic report No. 27. Moscow: World Bank in Russia. 


\section{Appendix: Questionnaire for Russian CEOs (major questions) ${ }^{11}$}

\section{Part 1. Current situation and perspectives}

1. What are the main lines of business of your firm?
A)
B)
C)

2. Approximate number of personnel in your company? persons

3. In terms of sales your firm is

Much smaller than the average firm of the industry 1

Slightly smaller than the average firm 2

Typical firm 3

Big firm 4

One of the largest firms

Other (please, specify)___ 6

4. What were the consequences of the financial crisis of 2008 to your industry (please, select one)?

Deep recession 1

Modest recession 2

Easy slowdown 3

No impact 4

Financial crisis accelerated the development of our industry 5

Other (please, specify)__ 6

5. What is the current situation of your major markets?

Recession 1

Stagnation $\quad 2$

Slow growth 3

Modest growth 4

Quick growth 5

Other (please, specify) ___ 6

\footnotetext{
${ }^{11}$ The original numbers of questions are not changed. The complete questionnaire is available from the author upon request.
} 
7. Your assessment of the current situation of your firm.

\begin{tabular}{|l|l|}
\hline Near bankruptcy & 1 \\
\hline Bad & 2 \\
\hline Satisfactory & 3 \\
\hline Good & 4 \\
\hline Excellent & 5 \\
\hline
\end{tabular}

9. What is the current level of competition in your industry?

\begin{tabular}{|l|l|}
\hline No competition & 1 \\
\hline A few firms does exist with gentlemen-like behavior & 2 \\
\hline Serious competition & 3 \\
\hline Strong competition & 4 \\
\hline Competition is extremely strong, all methods are used & 5 \\
\hline Other (please, specify) & 6 \\
\hline
\end{tabular}

10. Please, compare characteristics of your goods and services with those of direct competitors

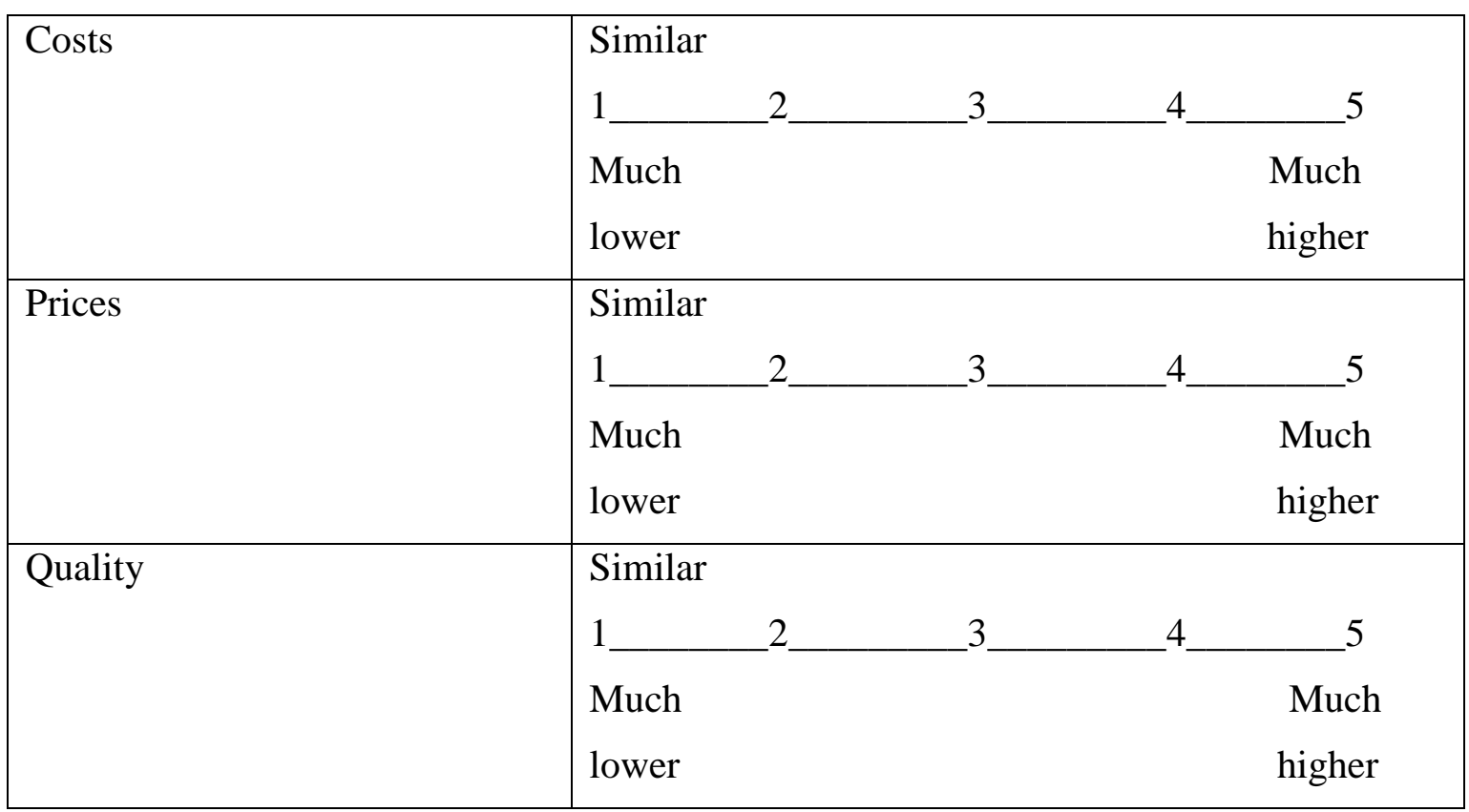

11. What is the ownership type of your firm?

\begin{tabular}{|l|c|}
\hline One owner & 1 \\
\hline A few owners & 2 \\
\hline Joint-stock company (closed or open) & 3 \\
\hline State ownership & 4 \\
\hline
\end{tabular}




\begin{tabular}{|l|l|}
\hline Subsidiary & 5 \\
\hline Other (please, specify)__ & 6 \\
\hline
\end{tabular}

12. What are the relationship between the firm and its shareholders (parent company, supervising government body)?

\begin{tabular}{|l|c|}
\hline Shareholders receive financial reports & 1 \\
\hline Shareholders retrace financial performance and determine the level of dividends & 2 \\
\hline Shareholders keep strategic control (innovations, investments, large contracts) & 3 \\
\hline $\begin{array}{l}\text { Shareholders keep both strategic and operational control (deliveries, product mix, } \\
\text { pricing) }\end{array}$ & 4 \\
\hline Owners are also top managers & 5 \\
\hline Other (please, specify) & 6 \\
\hline
\end{tabular}

13. What answer does describe the situation with production technologies in your industry?

\begin{tabular}{|l|c|}
\hline Technologies are stable & 1 \\
\hline Technologies are changing slowly & 2 \\
\hline Technologies are changing fast & 3 \\
\hline Technologies are changing extremely fast & 4 \\
\hline Other (please, specify) & 5 \\
\hline
\end{tabular}

14. What answer does describe the situation with new products in your industry?

\begin{tabular}{|l|c|}
\hline There are no new products & 1 \\
\hline New products appear from time to time & 2 \\
\hline New products appear regularly & 3 \\
\hline Other (please, specify) & 4 \\
\hline
\end{tabular}

15. What answer does describe the situation with sales technologies (placement, promotion) in your industry?

\begin{tabular}{|l|c|}
\hline Technologies are stable & 1 \\
\hline Technologies are changing slowly & 2 \\
\hline Technologies are changing fast & 3 \\
\hline Technologies are changing extremely fast & 4 \\
\hline Other (please, specify) & 5 \\
\hline
\end{tabular}


16. How do you adapt to changes in governmental regulation of business?

\begin{tabular}{|l|c|}
\hline We manage to foresee the changes in regulations and prepare beforehand & 1 \\
\hline $\begin{array}{l}\text { We are able to retrace the change and in most cases are capable to cope with the } \\
\text { changes without serious problems }\end{array}$ & 2 \\
\hline To adapt to the changes in regulations causes problems & 3 \\
\hline To adapt to the changes in regulations causes serious problems & 4 \\
\hline Other (please, specify) & 5 \\
\hline
\end{tabular}

17. In which extent the companies in your industry do coordinate their actions.

\begin{tabular}{|l|c|}
\hline There is no coordination at all & 1 \\
\hline Firms coordinate some actions sometimes & 2 \\
\hline Firms regularly coordinate their actions on a broad range of issues & 3 \\
\hline Firms regularly coordinate all their key actions & 4 \\
\hline Other (please, specify) & 5 \\
\hline
\end{tabular}

\section{Part 2. Innovations and investments}

1. How can you describe the actions implemented by your firm in 2010-the first half of 2011 ?

Not considered

Under consideration

Realized as trial projects

Realized regularly

$$
=1
$$$$
=2
$$$$
=3
$$

$=4$

\begin{tabular}{|l|c|c|c|c|}
\hline Action & \multicolumn{4}{l}{ Variant } \\
\hline Development of new business ideas & 1 & 2 & 3 & 4 \\
\hline $\begin{array}{l}\text { Development and launch of new products in the } \\
\text { traditional line of business }\end{array}$ & 1 & 2 & 3 & 4 \\
\hline $\begin{array}{l}\text { Development and launch of new products in a new } \\
\text { (for the firm) line of business }\end{array}$ & 1 & 2 & 3 & 4 \\
\hline Mastering new sales channels & 1 & 2 & 3 & 4 \\
\hline Purchase of patents and licenses & 1 & 2 & 3 & 4 \\
\hline Selling of patents and licenses & 1 & 2 & 3 & 4 \\
\hline Purchase and installation of new equipment & 1 & 2 & 3 & 4 \\
\hline Mastering new methods of quality control & 1 & 2 & 3 & 4 \\
\hline Mastering new methods of project financing & 1 & 2 & 3 & 4 \\
\hline Active recruitment of new personnel & 1 & 2 & 3 & 4 \\
\hline Use of new sources and methods of recruitment & 1 & 2 & 3 & 4 \\
\hline
\end{tabular}




\begin{tabular}{|l|c|c|c|c|}
\hline Use of new performance assessment methods & 1 & 2 & 3 & 4 \\
\hline Mastering new remuneration schemes & 1 & 2 & 3 & 4 \\
\hline Creation of new departments & 1 & 2 & 3 & 4 \\
\hline Spin-off of subsidiaries & 1 & 2 & 3 & 4 \\
\hline Acquisition of other firms & 1 & 2 & 3 & 4 \\
\hline
\end{tabular}

2. In which extent gave you used the services of independent contactors (strategic partners, specialized contractors, agents, technical and managerial consultants, staffing and training firms etc.) for ...

Such actions are not applicable in our industry $=0$

Do not use

$=1$

In a limited extent

$=2$

Active use

$=3$

\begin{tabular}{|l|l|l|l|l|}
\hline Type of actions & \multicolumn{4}{l|}{ Variant } \\
\hline Search of ideas for new goods and services & 0 & 1 & 2 & 3 \\
\hline Getting access to technologies & 0 & 1 & 2 & 3 \\
\hline Development of new technologies & 0 & 1 & 2 & 3 \\
\hline Identification of customers' requirements & 0 & 1 & 2 & 3 \\
\hline Prototype design & 0 & 1 & 2 & 3 \\
\hline Purchase of necessary equipment & 0 & 1 & 2 & 3 \\
\hline Installation and putting in motion of new equipment & 0 & 1 & 2 & 3 \\
\hline Staffing & 0 & 1 & 2 & 3 \\
\hline Mastering new methods of quality control & 0 & 1 & 2 & 3 \\
\hline Obtaining necessary state licenses and certificates & 0 & 1 & 2 & 3 \\
\hline Promotion campaign for new products & 0 & 1 & 2 & 3 \\
\hline Mastering new sales channels & 0 & 1 & 2 & 3 \\
\hline Design of new personnel performance methods & 0 & 1 & 2 & 3 \\
\hline Implementation of new remuneration schemes & 0 & 1 & 2 & 3 \\
\hline New training methods & 0 & 1 & 2 & 3 \\
\hline Change of organizational structure & 0 & 1 & 2 & 3 \\
\hline Spin-off of subsidiaries & 0 & 1 & 2 & 3 \\
\hline Acquisition of other firms & & 1 \\
\hline
\end{tabular}


3. How difficult is...

0 - this factor is not applicable to our industry

$1-$ not difficult

2 - moderately difficult

3 - extremely difficult

\begin{tabular}{|l|l|}
\hline Securing financing for a new project & $0 \_1 \_2 \_3$ \\
\hline Getting access to new technologies & $0 \_1 \_2 \_3$ \\
\hline $\begin{array}{l}\text { Installation, putting in motion and reaching the planned output of production } \\
\text { and other objects }\end{array}$ & $0 \_1 \_2 \_3$ \\
\hline Staffing by right personnel & $0 \_1 \_2 \_3$ \\
\hline Change of job duties of managers and workers & $0 \_1 \_2 \_3$ \\
\hline Orchestration of work of various departments & $0 \_1 \_2 \_3$ \\
\hline Control of innovation expenses & $0 \_1 \_2 \_3$ \\
\hline Understanding the customers' needs & $0 \_1 \_2 \_3$ \\
\hline Prototype design accordingly to customers' needs & $0 \_1 \_2 \_3$ \\
\hline Reaching the necessary quality level & $0 \_1 \_2 \_3$ \\
\hline Reaching the necessary level of technological discipline & $0 \_1 \_2 \_3$ \\
\hline Synchronization of suppliers & $0 \_1 \_2 \_3$ \\
\hline Pricing for a new product & $0 \_1 \_2 \_3$ \\
\hline Reaching mutual understanding with competitors & $0 \_1 \_2 \_3$ \\
\hline Obtaining necessary state licenses and certificates & $0 \_1 \_2 \_3$ \\
\hline Product promotion & $0 \_1 \_2 \_3$ \\
\hline Mastering (creating) sales channels & $0 \_1 \_2 \_3$ \\
\hline Use of new personnel assessment methods & $0 \_1 \_2 \_3$ \\
\hline Introduction of new remuneration and bonus schemes & $0 \_1 \_2 \_3$ \\
\hline Changes of organizational structures & $0 \_1 \_2 \_3$ \\
\hline Spin-off of subsidiaries & $0 \_1 \_2 \_3$ \\
\hline Purchase of other firms & $0 \_1 \_2 \_3$ \\
\hline
\end{tabular}




\section{Part 4. HRM}

5. How much did your firm spent on training in 2010 (courses, training, literature, coaching and mentoring etc.)?

\begin{tabular}{|l|c|}
\hline No expenses in 2010 & 1 \\
\hline Less than $1 \%$ of annual sales in 2010 & 2 \\
\hline $1-3 \%$ & 3 \\
\hline $3--10 \%$ & 5 \\
\hline More than $10 \%$ of annual sales in $2010 \Gamma$. & 6 \\
\hline Other (please, specify) & 4 \\
\hline
\end{tabular}

\section{Part 5. Organizational structure}

3. In which extent the firm's budget is centralized?

\begin{tabular}{|l|c|}
\hline All considerable expenses are approved by the top management & 1 \\
\hline $\begin{array}{l}\text { Middle managers have considerable budgets that they may use for their } \\
\text { departments' needs }\end{array}$ & 2 \\
\hline $\begin{array}{l}\text { Middle managers have considerable budgets and they may combine their } \\
\text { budgets for interests of several departments }\end{array}$ & 3 \\
\hline Other (please, specify) & 4 \\
\hline
\end{tabular}

5. How may you describe the current organizational climate?

\begin{tabular}{|l|c|}
\hline $\begin{array}{l}\text { Our company is like an extended family. Atmosphere is friendly, top } \\
\text { managers are considered as “older comrades". Organization is held together } \\
\text { by sensitivity to customers' and employees' needs. }\end{array}$ & 1 \\
\hline $\begin{array}{l}\text { Our firm is dynamic and creative place to work. Leaders are considers as } \\
\text { innovators with a bit of adventurism. The firms strives to open new horizons } \\
\text { and to capture new resources. Individual initiative, constant readiness to } \\
\text { change and to surpass competitors are encouraged. }\end{array}$ & 2 \\
\hline $\begin{array}{l}\text { Our firms is a set of well-built and effective procedures, processes and } \\
\text { structures. Leaders are good coordinators. This enables us to achieve stability } \\
\text { of our business. }\end{array}$ & 3 \\
\hline $\begin{array}{l}\text { Our organization is oriented towards properly measured financial results - } \\
\text { profitability and sales. To managers is trying to achieve such results my all } \\
\text { possible means. High demands are imposed on employees, internal } \\
\text { competition is encouraged }\end{array}$ & 4 \\
\hline Other (please, specify) & 5 \\
\hline
\end{tabular}


6. Which atmosphere do you like to see in your firm?

\begin{tabular}{|l|c|}
\hline $\begin{array}{l}\text { Our company is like an extended family. Atmosphere is friendly, top } \\
\text { managers are considered as "older comrades". Organization is held together } \\
\text { by sensitivity to customers' and employees' needs. }\end{array}$ & 1 \\
\hline $\begin{array}{l}\text { Our firm is dynamic and creative place to work. Leaders are considers as } \\
\text { innovators with a bit of adventurism. The firms strives to open new horizons } \\
\text { and to capture new resources. Individual initiative, constant readiness to } \\
\text { change and to surpass competitors are encouraged. }\end{array}$ & 2 \\
\hline $\begin{array}{l}\text { Our firms is a set of well-built and effective procedures, processes and } \\
\text { structures. Leaders are good coordinators. This enables us to achieve stability } \\
\text { of our business. }\end{array}$ & 3 \\
\hline $\begin{array}{l}\text { Our organization is oriented towards properly measured financial results - } \\
\text { profitability and sales. To managers is trying to achieve such results my all } \\
\text { possible means. High demands are imposed on employees, internal } \\
\text { competition is encouraged }\end{array}$ & 4 \\
\hline Other (please, specify) & 5 \\
\hline
\end{tabular}

\section{Some personal questions:}

1. Your age years

2. Your gender

$$
\text { Male - } 1 \text { Female - } 2
$$

3. The length of service in the present position with the present employer years

4. Your education

Economics

Management

Law

Humanities

Natural science

Engineering

Pedagogical

Medical

Military

Other (please, specify) 10 